\title{
Efforts to Improve Concept Understanding Energy Sources Through The Guided Discovery Learning Model In Primary School Students
}

\author{
Nuryanti \\ SD Negeri Sidasari 03 \\ Yantienur19@gmail.com
}

\section{Article History}

accepted 14/11/2020

approved $21 / 11 / 2020$

published 26/11/2020

\begin{abstract}
The study, entitled Efforts to Improve Understanding the Concept of the Benefits of Energy Sources through the Guided Discovery Learning Model of Elementary School Students in Class IV Semester 1 SD Negeri Sidasari 03 which aims to improve students' understanding of the concept of the benefits of energy sources with 11 research subjects consisting of 7 male students. male and 4 female students. This research was conducted because the students' conceptual understanding of the benefits of energy was still low. In cycle I, it shows that 3 students (60\%) have completed, 2 students (40\%) have not completed, and 6 students have not been able to take part in online evaluation activities. The research was continued in Cycle II with the results in cycle II showing 4 students (36\%) who did not complete, 7 students (64\%) of 11 students who did not complete. The use of the Guided Discovery Learning model can improve understanding of the concept of energy sources.
\end{abstract}

Keywords: effort, concept understanding, energy source

\begin{abstract}
Abstrak
Penelitian yang berjudul Upaya Peningkatan Pemahaman Konsep Manfaat Sumber Energi Melalui Model Guided Discovery Learning Siswa Sekolah Dasar di Kelas IV Semester 1 SD Negeri Sidasari 03 yang bertujuan untuk meningkatkan pemahaman konsep siswa terhadap materi manfaat sumber energi dengan subyek penelitian 11 siswa terdiri dari 7 siswa laki-laki dan 4 siswa perempuan. Penelitian ini dilakukan dikarenakan pemahaman konsep siswa terhadap materi manfaat energi masih rendah. Pada siklus I ini menunjukkan siswa yang tuntas sebanyak 3 siswa (60\%), siswa yang tidak tuntas sebanyak 2 siswa (40\%) dan 6 siswa belum bisa mengikuti kegiatan evaluasi secara daring. Penelitian dilanjutkan pada Siklus II dengan hasil pada siklus II ini menunjukkan siswa yang tuntas sebanyak 4 siswa $(36 \%)$, siswa yang tidak tuntas sebanyak 7 siswa (64\%) dari 11 siswa. Penggunaan model Guided Discovery Learning mampu meningkatkan pemahaman konsep materi sumber energi.
\end{abstract}

Kata kunci: upaya,pemahaman konsep,sumber energi

Social, Humanities, and Education Studies (SHEs): Conference Series https://jurnal.uns.ac.id/shes

p-ISSN 2620-9284

e-ISSN 2620-9292 


\section{PENDAHULUAN}

Berdasarkan nilai ulangan harian kelas IV SDN Sidasari 03 Cipari, diperoleh data bahwa pemahaman konsep siswa pada materi sumber energi masih tergolong rendah. Hal ini dapat dilihat pada perolehan hasil belajar siswa yang meliputi hasil ulangan harian, menunjukkan bahwa nilai rata-rata kelas masih dibawah nilai KKM 70 dengan jumlah keseluruhan 11 siswa.

Melalui hasil kajian pustaka ditemukan bahwa model pembelajaran Guided Discovery Learning memiliki potensi untuk meningkatkan pemahaman konsep siswa. Dengan menerapkan model Guided Discovery Learning pada materi sumber energi di SD Negeri Sidasari 03 Cipari maka siswa tidak mudah merasa bosan dan dapat berpartisipasi aktif selama kegiatan belajar mengajar berlangsung sehingga materi yang diajarkan guru dapat tersampaikan dengan baik dan hasilnya dapat terlihat dari pemahaman terhadap konsep manfaat sumber energi yang dapat dilihat melalui hasil evaluasi. Dengan penerapan rumusan tersebut siswa juga diharapkan untuk aktif dalam kegiatan pembelajaran sehingga siswa akan menemukan sendiri konsep yang akan ia pelajari.

Diharapkan setelah tindakan pembelajaran dilakukan, terdapat peningkatan pemahaman konsep siswa mengenai manfaat sumber energi dan nilai rata-rata ulangan harian dapat meningkat menjadi sekurang- kurangnya mencapai KKM yaitu 70. Berdasarkan identifikasi dan analisis masalah di atas, maka masalah dalam penelitian tindakan kelas ini di rumuskan sebagai berikut: (1) Bagaimana penerapan model Guided Discovery Learning dalam materi sumber energi pada siswa kelas IV SD Negeri Sidasari 03 Cipari ? (2) Apakah model Guided Discovery Learning dapat meningkatkan pemahaman konsep tentang sumber energi pada siswa kelas IV SD Negeri Sidasari 03 Cipari ?

Secara umum tujuan dari penelitian ini adalah untuk meningkatkan pemahaman konsep sumber energi pada siswa kelas IV SD Negeri Sidasari 03. Sedangkan tujuan khusus penelitian ini adalah untuk: (1) Mendeskripsikan penerapan model Guided Discovery Learning tentang sumber energi dalam kehidupan sehari-hari pada siswa kelas IV SD Negeri Sidasari 03 Cipari. (2) Meningkatkan pemahaman konsep siswa terhadap muatan pembelajaran IImu Pengetahuan Alam materi sumber energi pada siswa kelas IV SD Negeri Sidasari 03 menggunakan model Guided Discovery Learning.

\section{METODE}

Jenis penelitian yang dilakasanakan adalah Penelitian Tindakan Kelas (PTK) dengan subjek penelitian ini adalah siswa kelas IV SD Negeri Sidasari 03 Kecamatan Cipari Kabupaten Cilacap dengan jumlah siswa 11 yang terdiri dari 7 laki-laki dan 4 perempuan.Penelitian Tindakan Kelas ini dilaksanakan di SD Negeri Sidasari 03 Kecamatan Cipari Kabupaten Cilacap. Waktu penelitian ini dilaksanakan pada bulan Oktober hingga bulan November 2020. Pelaksanaan tindakan kelas selalu saling berkaitan dan berkesinambungan pada setiap prosesnya. Apabila siklus I belum mencapai target yang diharapkan, maka pada siklus selanjutnya dilakukan perbaikan melalui analisis masalah dan refleksi kegiatan. Teknik pengumpulan data dianggap paling penting dan utama dalam penelitian. Tanpa mengetahui teknik pengumpulan data maka peneliti tidak akan mendapatkan data yang memenuhi standar data yang ditetapkan. Teknik pengumpulan data yang digunakan dalam penelitian ini adalah menggunakan tes. Tes yang digunakan pada penelitian ini berbentuk pilihan ganda. Tes pemahaman konsep diberikan di akhir siklus dengan tujuan untuk mengukur sejauh mana pemahaman konsep siswa setelah pembelajaran menggunakan model Guided Discovery Learning. Instrumen penelitian adalah alat bantu yang dipilih dan digunakan oleh peneliti untuk kegiatan mengumpulkan data agar kegiatannya tersebut lebih sistematis dan lebih mudah. Instrumen yang digunakan dalam penelitian ini 
adalah menggunakan tes pemahaman konsep.Tes pemahaman konsep adalah tes yang digunakan untuk mengukur pencapaian seseorang setelah mengerjakan sesuatu. Tes dalam penelitian ini menggunakan tes obyektif berupa soal pilihan ganda. Soal tes yang digunakan terdiri dari tiga jenjang ranah kognitif, yaitu ingatan (C1), pemahaman (C2), dan penerapan (C3). Teknik analisis yang digunakan dalam penelitian ini adalah teknik deskriptif kuantitatif.

\section{HASIL DAN PEMBAHASAN}

Penelitian tindakan kelas Siklus I dilaksanakan pada hari Senin, 02 November 2020 secara daring melalui zoom dengan jumlah siswa sebanyak 11 siswa dan 5 siswa yang hadir dikarenakan tidak semua siswa memiliki handphone dan jaringan internet di daerah siswa masih sulit. Penelitian ini berlangsung selama satu kali tatap muka ( $2 \mathrm{x}$ 35 menit). Pada siklus I peneliti bertindak sebagai pengamat. Peneliti mengamati seluruh proses pembelajaran yang berlangsung pada siklus I diantaranya hasil belajar, kegiatan belajar siswa, dan kegiatan guru. Adapun hasil dari pengamatan peneliti pada siklus I adalah sebagai berikut:

Tabel 1 Hasil Belajar Siklus I

\begin{tabular}{llccl}
\hline No & \multicolumn{1}{c}{ Nama Siswa } & Kkm & Nilai & \multicolumn{1}{c}{ Ketrangan } \\
\hline 1 & Ahmad Sukron & 70 & 50 & Belum Tuntas \\
2 & Mohammad Jimmi Saputra & 70 & 80 & Tuntas \\
3 & Ngabdurrohim & 70 & 80 & Tuntas \\
4 Nur Khotijah & 70 & 60 & Belum Tuntas \\
5 Tri Minatasari & 70 & 90 & Tuntas \\
Jumlah & & 360 & \\
Rata-rata & & 72 & \\
Nilai Tertinggi & & 90 & \\
Nilai Terendah & & 50 & \\
Siswa Tuntas & & 3 & \\
Siswa Belum Tuntas & & 2 & \\
\hline
\end{tabular}

Berdasarkan hasil refleksi tindak lanjut penelitian tindakan kelas Siklus I, siswa belum bisa mengikuti pembelajaran dengan baik. Hal tersebut dapat dilihat masih terdapat 7 siswa yang belum tuntas dalam mencapai KKM. Hal tersebut juga menunjukkan masih kurangnya pemahaman konsep siswa dalam materi manfaat energi. Hasil belajar yang dicapai sudah cukup baik, tetapi jumlah siswa yang tuntas belajar belum mencapai $85 \%$, dan ketuntasan klasikal baru mencapai $45 \%$, sehingga target penelitian belum tercapai. Penelitian ini berlangsung selama satu kali tatap muka ( 2 × 35 menit). Pada siklus II peneliti bertindak sebagai pengamat. Peneliti mengamati seluruh proses pembelajaran yang berlangsung pada siklus II diantaranya hasil belajar, kegiatan belajar siswa, dan kegiatan guru. Adapun hasil dari pengamatan peneliti pada siklus II adalah sebagai berikut: 
Tabel 2. Hasil Belajar Siklus I dan Siklus II

\begin{tabular}{|c|c|c|c|c|c|}
\hline No & Nama Siswa & Kkm & Siklus I & Siklus li & Ketarangan \\
\hline 1 & Aditiya Bayu Afian & 70 & & 60 & Belum Tuntas \\
\hline 2 & Ahmad Sukron & 70 & 50 & 50 & Belum Tuntas \\
\hline 3 & Cahya Rahmat Risqi & 70 & & 50 & Belum Tuntas \\
\hline 4 & Dwi Saputra & 70 & & 60 & Belum Tuntas \\
\hline 5 & Heru Aditiya & 70 & & 70 & Tuntas \\
\hline 6 & Irma Wati & 70 & & 60 & Tuntas \\
\hline 7 & Irna Wati & 70 & & 50 & Belum Tuntas \\
\hline 8 & Muhammad Jimmi & 70 & 80 & 70 & Tuntas \\
\hline 9 & Ngabdurrohim & 70 & 80 & 70 & Tuntas \\
\hline 10 & Nur Khotijah & 70 & 60 & 60 & Belum Tuntas \\
\hline 11 & Tri Mianatasari & 70 & 90 & 80 & Tuntas \\
\hline \multicolumn{2}{|c|}{ Jumlah } & & 360 & 680 & \\
\hline \multicolumn{2}{|c|}{ Rata-rata } & & 72 & 62 & \\
\hline \multicolumn{2}{|c|}{ Nilai Tertinggi } & & 90 & 80 & \\
\hline \multicolumn{2}{|c|}{ Nilai Terendah } & & 50 & 50 & \\
\hline \multicolumn{2}{|c|}{ Siswa Tuntas } & & 3 & 5 & \\
\hline \multicolumn{2}{|c|}{ Siswa Belum Tuntas } & & 2 & 6 & \\
\hline
\end{tabular}

\section{SIMPULAN}

Berdasarkan rumusan masalah dan analisa data hasil penelitian dan pembahasan Penelitian Tindakan Kelas ini, dapat disimpulkan sebagai berikut : Pemahaman konsep siswa kelas IV SD Negeri Sidasari 03 pada materi sumber energi melalui model Guided Discovery Learning mengalami peningkatan meskipun tidak signifikan dalam ketuntasan belajar, namun dari segi partisipasi. Untuk mencapai ketuntasan KKM minimal 85\% maka penelitian akan dilanjutkan pada Siklus III dengan harapan tingkat pemahaman konsep siswa terhadap materi sumber energi semakin meningkat dan dapat mencapai KKM.

\section{DAFTAR PUSTAKA}

IGAK Wardani,Kuswaya Wihardit, Penelitian Tindakan Kelas, (Jakarta: Universitas Terbuka, 2008), Cet.7, hal.1.3

Wardhani, IGAK dan Wihardit, Kuswaya. 2008. Penelitian Tindakan Kelas. Jakarta : Universitas Terbuka

J.W.S Poerwodarminto (Badriyah), Pengertian Pemahaman Konsep , 2011

Arends, R I. (2012). Learning to Teach ninth edition. New York : McGraw-Hill

Carin and Sund. 1989. Teaching Science Throught Discovery Colombus, Ohio: Merril Publishing Company.

Wenning, C.J. (2011). The Levels of Inquiry Model of Science Teaching. Journal of Physics Techer Education Online, 6(2), Summer 2011 (9-20)

Westwood, Petter. 2008. What Teacher Need To Now About Teaching Methods. Autralia: Ligare.

Hosnan. 2014. Pendekatan Saintifik dan Kontekstual dalam Pembelajaran Abad 21. Bogor : Ghalia Indonesia.

Hanafiah. (2012). Konsep Strategi Pembelajaran. Bandung: Refika Aditama. 